\title{
The Barriers of PJOK Teachers in the Implementation of Swimming Learning at Elementary School Kulon Progo Regency
}

\author{
Hedi Ardiyanto Hermawan ${ }^{1, *}$ Nur Sita Utami ${ }^{1}$, Anida Purwandari ${ }^{1}$, Subagyo \\ Subagyo ${ }^{1}$
}

${ }^{1}$ Fakultas Ilmu Keolahragaan, Universitas Negeri Yogyakarta Yogyakarta, Indonesia

*Corresponding author. Email: hedi_ardiyanto@uny.ac.id

\begin{abstract}
This study aims to determine how high the barriers of PJOK teachers are to the implementation of swimming lessons in State Elementary Schools in Kokap District, Kulon Progo Regency. This research is quantitative descriptive. The place and time of this research were carried out in State Elementary Schools in Kokap District, Kulon Progo Regency, August $1-14,2021$. The method in this study used a survey method with the technique of collecting data using a questionnaire/questionnaire. The data analysis technique in this study used a descriptive technique in the form of a percentage. The population in this study were PJOK teachers at public elementary schools in the Kokap sub-district, Kulon Progo Regency, totalling 16 PJOK teachers. The results showed that the barriers for physical education teachers to the implementation of learning in State Elementary Schools throughout the Kokap District, Kulon Progo Regency, which were included in the very high category were $6 \%$, the high category was $56 \%$, the excellent category was $19 \%$, the low category was $13 \%$, and the deficient category was $13 \%$. $6 \%$.
\end{abstract}

Keywords: PJOK Teacher Barriers, Learning, Swimming.

\section{INTRODUCTION}

Physical education is one of the subjects in schools that use the means of movement or physical activity in achieving student development. Physical education carried out in schools aims to improve a learning process, namely developing motor skills, physical fitness, knowledge, healthy and active behaviour, emotional intelligence and sportsmanship.

The objectives of physical education to be achieved include development in the psychomotor, cognitive, and affective domains. The objectives of physical education can be achieved by having several essential components, among others, learning objectives, educators/teachers, students, and other facilities (such as media, facilities and infrastructure) to support the ongoing learning process.

Swimming is one of the primary materials in learning physical education in elementary schools. Swimming is an activity that uses many parts of the body, especially the hands and feet, to move or float in the water. Swimming can be carried out in the water. Thus water is the primary means for carrying out swimming activities. Activities carried out in the water are very different from activities on land because there is pressure in the water. Therefore, it is necessary to introduce the characteristics of water so that it can adapt to the properties of translucent water and others so that students can adjust themselves when doing activities in the water.

There are four styles in swimming, namely, breaststroke, backstroke, freestyle, and butterfly. But in elementary school, swimming lessons are only taught from grades 4-6 with freestyle and breaststroke material. The benefits of swimming include maintaining and improving fitness, maintaining a healthy body, being able to stimulate motor movements as a form of selfpreservation in the water, exercising muscle strength, heart and lungs, as well as being beneficial for children's physical development and growth, for educational and recreational facilities. And achievements. Judging from the benefits of swimming, swimming has been included in the world of education from elementary to high school. The success of the swimming learning process in schools is not far from the role of an educator/teacher. 
Physical education teachers have weighty duties and responsibilities. Therefore, physical education teachers must have good abilities and skills so that swimming lessons can be conveyed to students and can meet the curriculum or goals that have been set. Swimming lessons in elementary schools may or may not be implemented. To achieve quality learning, the existence of quality teachers is an absolute requirement because the learning process in schools lies in the hands of a teacher, starting from its implementation, mastery of the material, and how to manage to learn. Teachers are also expected to be able to present a varied learning process and can improve the personality, morals, and development of students, both the development of interests, talents, abilities, and potential of students.

Based on the results of field observations conducted on physical education teachers at one of the public elementary schools included in the Kokap District area, namely the Clapar State Elementary School, it shows that teachers are tough to carry out swimming lessons are constrained by several factors that are believed to be obstacles. This is evidenced by the fact that there are some students who do not understand the basic movements of swimming. It turns out that in the process of learning to swim, many obstacles are often encountered. The activities of the swimming learning process at the Clapar State Elementary School in Kokap District were not running optimally due to several factors, namely the limited facilities and infrastructure for implementing swimming lessons, the distance from the school to the swimming pool is very far, there are still many students who are afraid of water. In addition, the lack of knowledge and strategies of teachers in implementing swimming lessons, causing incompatibility of teaching materials with the implementation of swimming lessons. It is proven that swimming lessons for students in grades IV, V and VI of State Elementary Schools in the Kokap sub-district, are carried out at an uncertain time, sometimes even not implemented, and there are some who do not implement it at all. With the following circumstances, the researcher hopes that as a physical education teacher, he must be more creative in teaching, especially when learning swimming, because even though there are infrastructure, facilities and other obstacles, if the teacher has a creative mind, learning will still be carried out properly.

To find out the existing obstacles, it can be done by looking at all the factors, these factors include: educator factors, student factors, facilities and infrastructure factors, teaching material factors, non-teaching staff factors, and environmental factors. Therefore, the researchers wanted to find out how high the barriers to the implementation of swimming lessons were in all these elementary schools, so the researchers proposed a study entitled "Barriers of PJOK Teachers to the Implementation of Swimming Learning in State
Elementary Schools in Kokap District, Kulon Progo Regency".

\section{METHOD}

\subsection{Types of research}

This research uses descriptive quantitative research. The method used is a survey method with data collection techniques in the form of a questionnaire. Questionnaire (questionnaire) is a data collection technique that is carried out by giving a set of questions or written statements to respondents to answer (Sugiyono, 2017: 199). In this way, the research variables studied were in the form of a set of data to be presented regarding the barriers of PJOK teachers to the implementation of swimming lessons in State Elementary Schools throughout the Kokap District, Kulon Progo

\subsection{Research Time and Place}

This research started from April to August 2021 or approximately four months which was carried out at State Elementary Schools throughout the Kokap District, Kulon Progo Regency.

\subsection{Research Subject}

The subjects of this study were PJOK teachers, totalling 16 people. This subject was obtained through taking the entire population of PJOK teachers who were in public elementary schools throughout the Kokap District, Kulon Progo Regency.

\subsection{Data Collection Instruments and Techniques}

Research instruments are tools used by researchers in their research to collect data. The instrument and technique of data collection in this research is to use a questionnaire in the form of a questionnaire. This research instrument uses an instrument that has been researched by Dimas Prasetyo. Then this research instrument is a modification of Dimas Prasetyo's questionnaire. To provide an overview of the questionnaire used in this study, a grid of research instruments is presented in Table 6 as follows:

\section{RESULTS}

\subsection{Results}

The results of the research on the obstacles of PJOK teachers to the implementation of swimming learning in State Elementary Schools throughout the Kokap District, Kulon Progo Regency, this study was measured by 16 respondents and 42 statement items, a score range of 1-4 
which was divided into several factors, namely educators, students, curriculum factors, infrastructure, non-teaching staff, and the environment.

In this study, physical education teachers' barriers to the implementation of swimming lessons in State Elementary Schools throughout the Kokap District, Scalar variables and physical constants should be italicized, and a bold (non-italics) font should be used for vectors and matrices. Do not italicize subscripts unless they are variables. Equations should be either display (with a number in parentheses) or inline. Use the built-in Equation Editor or MathType to insert complex equations.

\subsubsection{Educator Factor (Teacher)}

Based on the table above, it shows that the barriers of PJOK teachers to the implementation of swimming learning in State Elementary Schools throughout the Kokap District, Kulon Progo Regency based on educator factors that are included in the very high category of $6 \%$, high category of $13 \%$, sufficient category of $56 \%$, low category of $19 \%$, and very low at $6 \%$,

Table 1. Research Results of Educators

\begin{tabular}{|c|c|c|c|}
\hline Interval & category & frequency & $\begin{array}{c}\text { Percent } \\
\text { (\%) }\end{array}$ \\
\hline $\mathrm{X}>36,5$ & very high & 1 & 6 \\
\hline $\begin{array}{c}36,5<\mathrm{X} \leq \\
41,5\end{array}$ & high & 2 & 13 \\
\hline $\begin{array}{c}41,5<\mathrm{X} \leq \\
46,5\end{array}$ & Enough & 9 & 56 \\
\hline $\begin{array}{c}46,5<\mathrm{X} \leq \\
51,5\end{array}$ & Low & 3 & 19 \\
\hline $\begin{array}{c}\mathrm{X} \leq 51,5 \\
\text { Very low }\end{array}$ & 1 & 6 \\
\hline \multicolumn{2}{|c|}{ Amount } & 16 & 100 \\
\hline
\end{tabular}

\subsubsection{Student Factor (Teacher)}

Based on the table above, it shows that the barriers of PJOK teachers to the implementation of swimming learning in Public Elementary Schools throughout the Kokap District, Kulon Progo Regency based on the factors of students who fall into the very high category of $0 \%$, high category of $38 \%, 56 \%$ sufficient, low category of $0 \%$, category, and very low category of $6 \%$.

Table 2. Research Results on Student Factors

\begin{tabular}{|c|c|c|c|}
\hline Interval & category & frequency & percent\% \\
\hline $\mathrm{X}>20$ & very high & 0 & 0 \\
\hline
\end{tabular}

\begin{tabular}{|c|c|c|c|}
\hline $\begin{array}{c}18<\mathrm{X} \leq \\
20\end{array}$ & high & 6 & 38 \\
\hline $\begin{array}{c}16<\mathrm{X} \leq \\
18\end{array}$ & Enough & 9 & 56 \\
\hline $\begin{array}{c}14<\mathrm{X} \leq \\
16\end{array}$ & Low & 0 & 0 \\
\hline $\mathrm{X} \leq 14$ & Very low & 1 & 6 \\
\hline \multicolumn{2}{|c|}{ Amount } & 16 & 100 \\
\hline
\end{tabular}

\subsubsection{Factors of Teaching Materials (Curriculum)}

Based on the table above, it shows that the barriers of PJOK teachers to the implementation of swimming learning in State Elementary Schools throughout the Kokap District, Kulon Progo Regency based on teaching material factors (curriculum) which are included in the very high category of $13 \%$, high category of $6 \%$, adequate category of $75 \%$, the low category is $6 \%$, and the very low category is $0 \%$.

Table 3. Research Results of Teaching Material Factors

\begin{tabular}{|c|c|c|c|}
\hline Interval & category & frequency & percent\% \\
\hline $\mathrm{X}>14.5$ & very high & 2 & 13 \\
\hline $\begin{array}{c}13.5<\mathrm{X} \leq \\
14.5\end{array}$ & high & 1 & 6 \\
\hline $\begin{array}{c}12.5<\mathrm{X} \leq \\
13.5\end{array}$ & Enough & 12 & 75 \\
\hline $\begin{array}{c}11.5<\mathrm{X} \leq \\
12.5\end{array}$ & Low & 1 & 6 \\
\hline $\mathrm{X} \leq 11.5$ & Very low & 0 & 0 \\
\hline \multicolumn{2}{|c|}{ Amount } & 16 & 100 \\
\hline
\end{tabular}

\subsubsection{Infrastructure Factor}

Based on the table above, it shows that the barriers of PJOK teachers to the implementation of swimming learning in State Elementary Schools throughout the Kokap District, Kulon Progo Regency based on infrastructure factors that fall into the very high category of $6 \%$, high category of $25 \%$, sufficient category of $38 \%$, low category by $12 \%$, and very low category by $19 \%$.

Table 4. Research Results on Infrastructure Factors

\begin{tabular}{|c|c|c|c|}
\hline Interval & category & frequency & percent $\%$ \\
\hline $\mathrm{X}>13.5$ & very high & 1 & 6 \\
\hline
\end{tabular}




\begin{tabular}{|c|c|c|c|}
\hline $\begin{array}{c}12.5<\mathrm{X} \leq \\
13.5\end{array}$ & high & 4 & 25 \\
\hline $\begin{array}{c}11.5<\mathrm{X} \leq \\
12.5\end{array}$ & Enough & 6 & 38 \\
\hline $\begin{array}{c}10.5<\mathrm{X} \leq \\
11.5\end{array}$ & Low & 2 & 12 \\
\hline $\mathrm{X} \leq 10.5$ & Very low & 3 & 19 \\
\hline \multicolumn{2}{|c|}{ Amount } & 16 & 100 \\
\hline
\end{tabular}

\subsubsection{Non-Educator Factors}

Based on the table above, it shows that the barriers of PJOK teachers to the implementation of swimming learning in State Elementary Schools throughout the Kokap District, Kulon Progo Regency based on the factors of non-teaching staff who fall into the very high category at $0 \%$, high category by $44 \%$, sufficient category by $31 \%$, category low by $19 \%$, and very low category by $6 \%$.

Table 5. Research Results on Non-Educator Factors

\begin{tabular}{|c|c|c|c|}
\hline Interval & category & frequency & percent\% \\
\hline $\mathrm{X}>18$ & very high & 0 & 0 \\
\hline $\begin{array}{c}16<\mathrm{X} \leq \\
18\end{array}$ & high & 7 & 44 \\
\hline $\begin{array}{c}14<\mathrm{X} \leq \\
16\end{array}$ & Enough & 5 & 31 \\
\hline $\begin{array}{c}12<\mathrm{X} \leq \\
14\end{array}$ & Low & 3 & 19 \\
\hline $\begin{array}{c}\mathrm{X} \leq 12 \\
\text { Amount }\end{array}$ & 16 & 100 \\
\hline \multicolumn{2}{|c|}{ Very low } & 1 & 6 \\
\hline
\end{tabular}

\subsubsection{Environmental Factors}

Based on the table above, it shows that the barriers of PJOK teachers to the implementation of swimming learning in State Elementary Schools throughout the Kokap District, Kulon Progo Regency based on environmental factors that fall into the very high category of $0 \%$, high category of $50 \%$, sufficient category of $31 \%$, low category of $13 \%$, and very low category by $6 \%$.

Table 6. Research Results on Environmental Factors

\begin{tabular}{|c|c|c|c|}
\hline Interval & category & frequency & percent\% \\
\hline $\mathrm{X}>18,5$ & very high & 0 & 0 \\
\hline $\begin{array}{c}15,5<\mathrm{X} \leq \\
18,5\end{array}$ & high & 8 & 50 \\
\hline
\end{tabular}

\begin{tabular}{|c|c|c|c|}
\hline $\begin{array}{c}12,5<\mathrm{X} \leq \\
15,5\end{array}$ & Enough & 5 & 31 \\
\hline $\begin{array}{c}9,5<\mathrm{X} \leq \\
12,5\end{array}$ & Low & 2 & 13 \\
\hline $\mathrm{X} \leq 9,5$ & Very low & 1 & 6 \\
\hline \multicolumn{2}{|c|}{ Amount } & 16 & 100 \\
\hline
\end{tabular}

\subsubsection{Environmental Factors}

Based on the table above, it shows that the barriers of PJOK teachers to the implementation of swimming lessons in public elementary schools throughout the Kokap sub-district, Kulon Progo Regency which are included in the very very high category are $6 \%$, the high category is $56 \%$, the sufficient category is $19 \%$, the low category is $13 \%$, and very low category by $6 \%$.

Table 7. Overall Factor Research Results

\begin{tabular}{|c|c|c|c|}
\hline Interval & category & frequency & percent\% \\
\hline $\mathrm{X}>18,5$ & very high & 0 & 0 \\
\hline $\begin{array}{c}15,5<\mathrm{X} \leq \\
18,5\end{array}$ & high & 8 & 50 \\
\hline $\begin{array}{c}12,5<\mathrm{X} \leq \\
15,5\end{array}$ & Enough & 5 & 31 \\
\hline $\begin{array}{c}9,5<\mathrm{X} \leq \\
12,5\end{array}$ & Low & 2 & 13 \\
\hline $\mathrm{X} \leq 9,5$ & Very low & 1 & 6 \\
\hline \multicolumn{2}{|c|}{ Amount } & 16 & 100 \\
\hline
\end{tabular}

\section{DISCUSSION}

Swimming is a fun water sport and is very popular, especially among elementary school-age children. Swimming is a sport that is popular among the public, be it children, adults, or the elderly. Swimming is a sport that is carried out in the water with the aim of recreation, rehabilitation, achievement, education and can be done by all groups. Swimming is a sport that is quite difficult for some students to do, because swimming is done in water and there are many obstacles experienced in the learning process.

Barriers are things that are the cause or because only the goal or desire cannot be realized. Barriers are anything that makes a barrier in carrying out activities or actions in carrying out a program so that it can result in less successful achievement of the program's goals.

Based on the results of the study, it was shown that the barriers of PJOK teachers to the implementation of 
swimming lessons in State Elementary Schools throughout the Kokap District, Kulon Progo Regency, which were included in the very high category were $6 \%$, the high category was $56 \%$, the excellent category was $19 \%$, the low category was $13 \%$, and deficient category by $6 \%$. These results can be interpreted that the barriers of PJOK teachers to the implementation of swimming lessons in State Elementary Schools throughout the Kokap District, Kulon Progo Regency are partly in the high category. Based on these results, it shows that swimming learning is less than optimal. This is due to several factors, including educators (teachers), students (students), curriculum (materials), facilities and infrastructure, non-teaching staff and the environment.

In detail, the obstacles for PJOK teachers to the implementation of swimming lessons in public elementary schools throughout the Kokap sub-district, Kulon Progo Regency based on the factors of educators (teachers), students (students), curriculum (materials), facilities and infrastructure, non-educational staff and the environment are explained as follows;

Firstly, educator factor (teachers), the obstacles of PJOK teachers to the implementation of swimming lessons in State Elementary Schools throughout the Kokap District, Kulon Progo Regency based on the factor of educators (teachers) are in the excellent category. The teacher is a significant factor that will affect the learning process to run smoothly. Barriers based on educational factors (teachers) so far are due to teachers in providing less creative/varied material so that children tend to feel bored quickly. The lack of interaction between teachers and students is also very influential in the implementation of this learning. In addition, the lack of knowledge and skills of teachers on swimming learning materials is also an obstacle to learning.

Secondly, Student Factors (students). PJOK teachers' barriers to the implementation of swimming lessons in State Elementary Schools throughout the Kokap District, Kulon Progo Regency based on the student factor (students) are in the sufficient category. Barriers based on students mean that students themselves have difficulties in mastering basic swimming techniques. There are some students who have a history of certain diseases, are afraid of water, and many students ask for permission during learning so that learning is hampered. Therefore, students must be trained mentally so as not to be afraid of water. In addition, students must also have high motivation and be happy/excited about learning to swim so that the delivery of material will feel more easily absorbed.

Thirdly, Factors of Teaching Materials (curriculum). The obstacles of PJOK teachers to the implementation of swimming lessons in State Elementary Schools throughout the Kokap District, Kulon Progo Regency based on the teaching material factor (curriculum) are in a good category. Barriers based on teaching material factors are due to the lack of time allocation for swimming lessons, so there are still many students who do not understand the material given. In addition, the hours used in learning are only one meeting in 1 month, and there are some elementary schools that even only hold one meeting in 2 semesters. This greatly hinders the implementation of swimming lessons.

Fourth, Facilities and Infrastructure Factors. The obstacles of PJOK teachers to the implementation of swimming lessons in State Elementary Schools throughout the Kokap District, Kulon Progo Regency based on facilities and infrastructure factors in the good category. Barriers based on facilities and infrastructure factors are the limited facilities and infrastructure for swimming lessons that are inadequate/rented so that students cannot freely practice or carry out swimming lessons.

Fifth, Non-Educator Factors. PJOK teachers' barriers to the implementation of swimming lessons in State Elementary Schools throughout the Kokap District, Kulon Progo Regency based on the factor of nonteaching staff are in the high category. Barriers based on non-educational staff are caused by the lack of accompanying teachers when doing swimming lessons. In addition, the costs incurred to carry out swimming lessons are not small so that it becomes an inhibiting factor for both parents and schools.

Sixth, Environmental Factors. PJOK teachers' barriers to implementing swimming lessons in State Elementary Schools throughout the Kokap District, Kulon Progo Regency based on environmental factors are in the high category. Barriers based on environmental factors due to the distance between the school and the swimming pool are quite far and the road conditions that go up and down cause a considerable risk because it is considered dangerous.

Based on the research data above, it can be concluded that the biggest obstacle experienced by physical education teachers so that the implementation of swimming learning cannot run optimally. The most inhibiting factor is environmental factors.

\section{CONCLUSION}

Based on the results of previous research and discussion, it is known that the barriers for PJOK teachers to the implementation of swimming lessons in State Elementary Schools throughout the Kokap District, Kulon Progo Regency are included in the deficient category by $6 \%$, the low category by $13 \%$, the sufficient category by $19 \%$, the high category by $56 \%$, and very high category of $6 \%$. These results can be interpreted that the barriers for physical education teachers to the implementation of swimming lessons in State Elementary Schools throughout the Kokap District, Kulon Progo Regency have a percentage of $56 \%$. 


\section{REFERENCES}

[1] Slameto. (2013). Belajar dan faktor-faktor yang mempengaruhinya. Jakarta: PT Rineka Cipta.

[2] Sugiyono. (2001). Metode penelitian. Bandung: Alfabeta.

[3] Sugiyono, Sugiyono (2010) Metode Penelitian Kuantitatif dan Kualitatif dan R\&D. ALFABETA Bandung.

[4] Dimas, Prasetyo. (2020). Hambatan guru penjasorkes terhadap pelaksanaan pembelajaran renang di SD Negeri se-Kecamatan Lendah. Skripsi. Yogyakarta:Fakultas Ilmu Keolahragaan. UNY.

[5] Sukintaka. (2004:55) Tujuan pendidikan jasmani. Jakarta: Depdikbud.

[6] Karnadi, Indik. (2007). Renang. Jakarta: Universitas Terbuka.

[7] Kurniawan. (2019). Peta konsep materi renang. Jakarta: Gramedia Pustaka.

[8] Kurniawati, Nani. (2014). Renang itu mudah. Bandung: PT Remaja Rosdakarya. 